\title{
C C
}
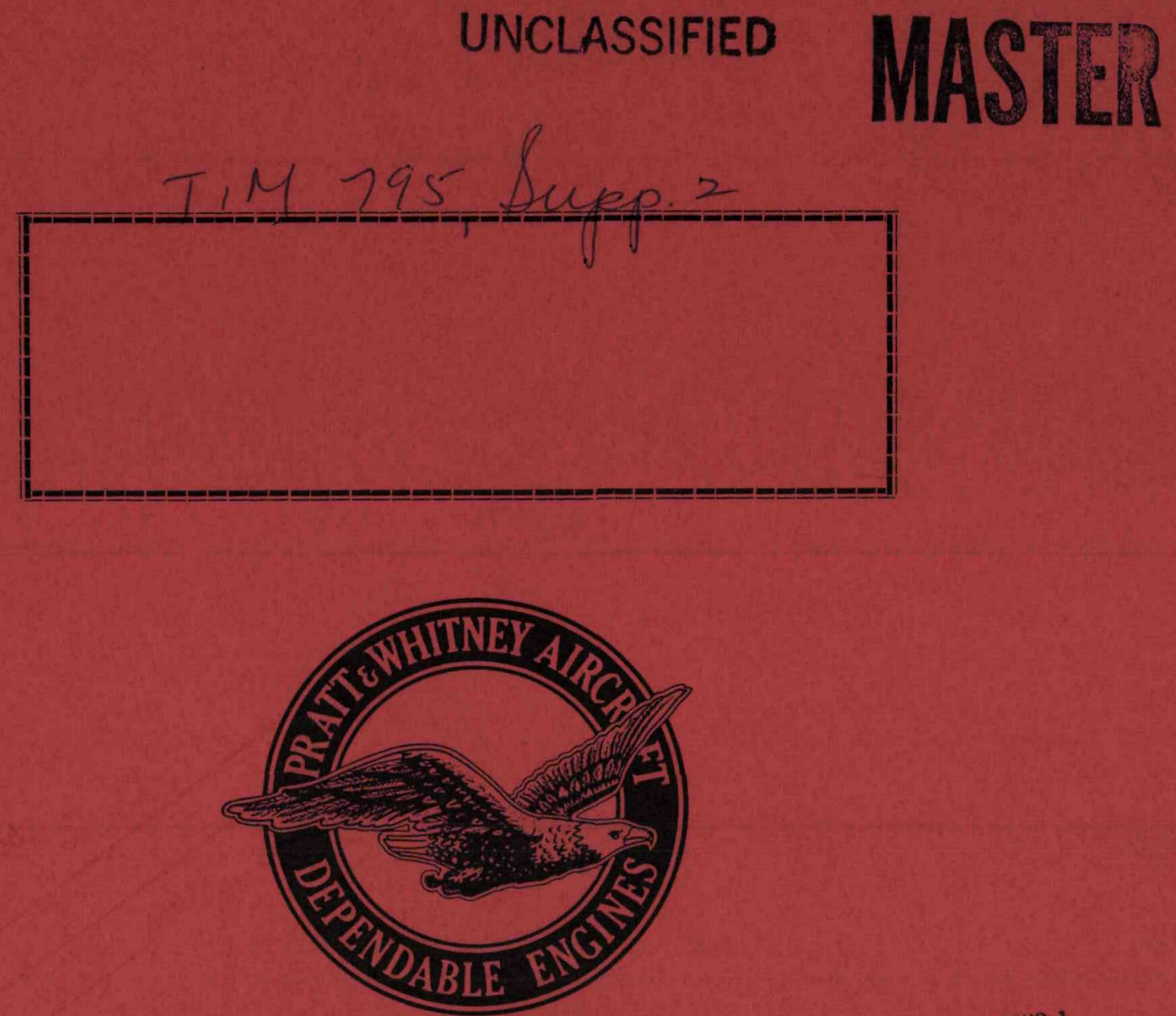

GROUP 1

\section{RESTRICIED DATA}

This documentsontainstrestricted data as defined in the Atomic Energy Act of 1954. Its transmittal or the disclosure of its contents in any manner to an unauthorized person is prohibited.

$\begin{array}{lllllllllllllllllllll}\text { P } & R & A & T & T & E & W & H & \text { I } & T & N & E & Y & A & \text { I } & R & C & R & A & F & T\end{array}$ DIVISION OF UNITED AIRCRAFT CORPORATION C A NEL 


\section{DISCLAIMER}

This report was prepared as an account of work sponsored by an agency of the United States Government. Neither the United States Government nor any agency Thereof, nor any of their employees, makes any warranty, express or implied, or assumes any legal liability or responsibility for the accuracy, completeness, or usefulness of any information, apparatus, product, or process disclosed, or represents that its use would not infringe privately owned rights. Reference herein to any specific commercial product, process, or service by trade name, trademark, manufacturer, or otherwise does not necessarily constitute or imply its endorsement, recommendation, or favoring by the United States Government or any agency thereof. The views and opinions of authors expressed herein do not necessarily state or reflect those of the United States Government or any agency thereof. 


\section{DISCLAIMER}

Portions of this document may be illegible in electronic image products. Images are produced from the best available original document. 


\section{PRATT \& WHITNEY AIRCRAFT \\ CANVEL.}

TECHNICAL INFORMATION MEMORANDUM

SUBHCR: One Dimensionel Trangport Caiculations of Self Shielding Factors Por In-Pile Capsule Pests

CODIES TO: R. Strough, E. Dytko,

C. Bigellow, G. Parks, h. Froder, R. Doek,

D. Vassallo, M. Zelssex, M. DeCrescenti, U. Ackermann V. Scotti, F. Felber, J. Krause,
TRM NO. 795, Supp.?

DATE OP REPORT: ApXSI 27, 1964

WRITTEN BY:

J. Krause

APPROVED BY: E. J० Richings

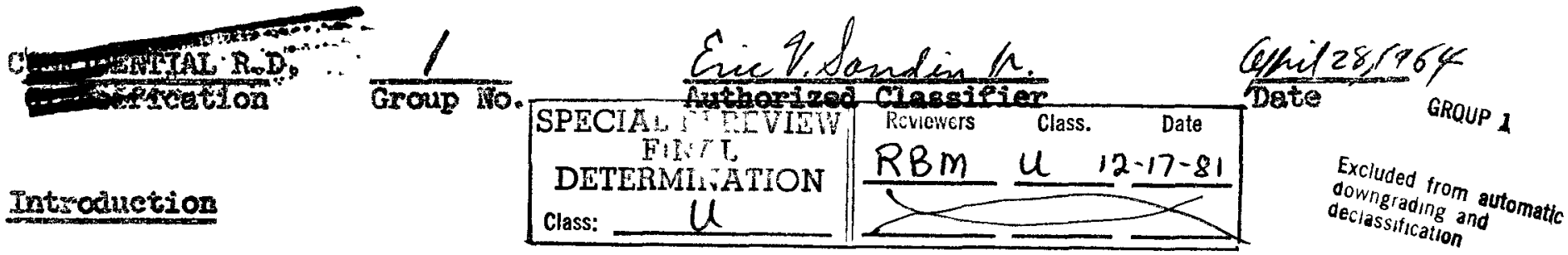

The design of Inpile terts of SWAP-50 Iuel elenents requires a knowedge of the depression $c t$ the tegt reactor flux due to the preaence of the fuel test capeule. There are three pxinary efpects which contribute to the flux depression as follow:

1. Introduction of the capsule into the test hole displaces water thus reduciog the local thermal flux.

2. Since the cepsule contains considereble structural material, Iiquid metal coolant, heaters, etc. sowe thus depression occurs due to absorption in non Fuel mater.ials.

3. Burther flux depression occurg due to the fuel specimen itself.

In this report the reauits of Sn tmansport celculations (DTK eode) of the effective belf shielding ractors for in-pile tests of UN and UC fuels are given. Cylinorical rociups were Drepared to represent test Locations in ETR, MIR and GETR and the effective self shielding pactor yersus fuel enichent was determined. The effect of a tuagsten diffusion barrier and of changes in fuel specinen dianeter were also obtained. AlI celculations are based on the fuel test eapsule deslon described in TIT 715 .

As chect on the velidity of the caleulated flux spectra, the cadmium ratio as

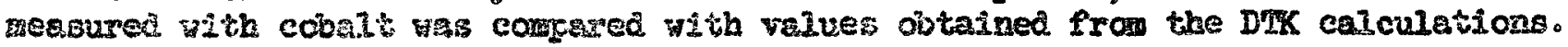

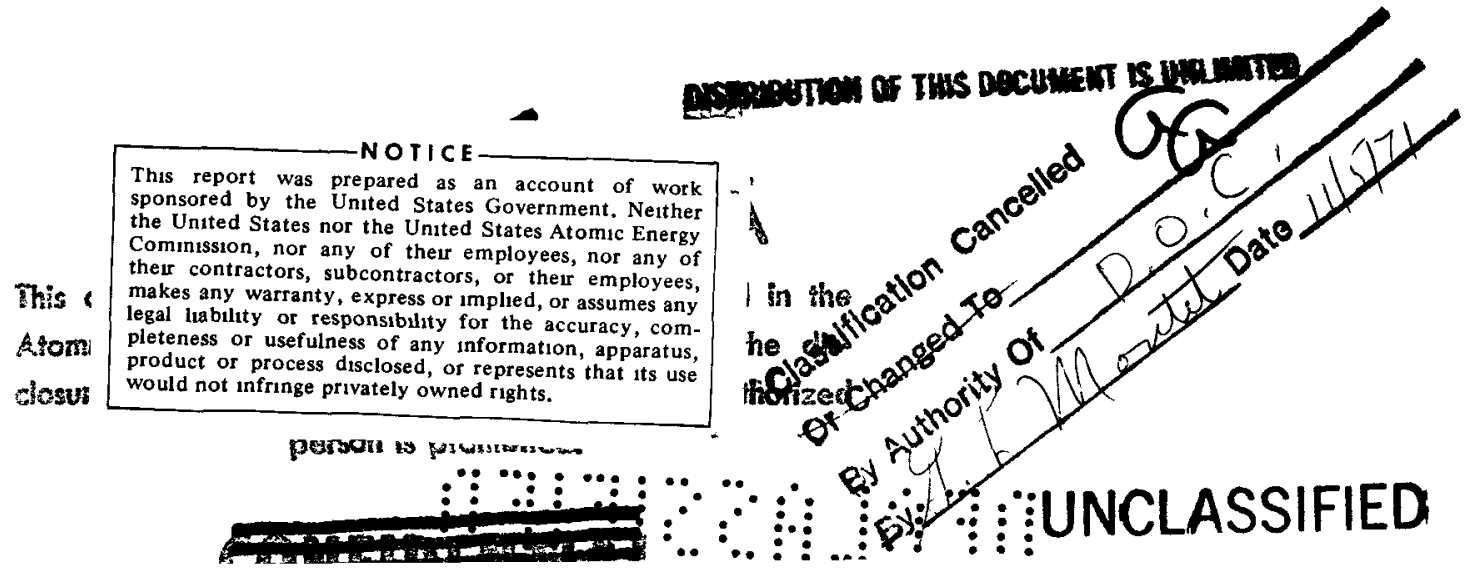


Method and Reaul's

The erfective self shieiding factor $f_{0}(\epsilon)$ is defined as sollows:

$$
f_{0}(\epsilon) \equiv \frac{\sigma}{\sum_{f}^{i n}(\epsilon) \phi_{t h}^{0}}
$$

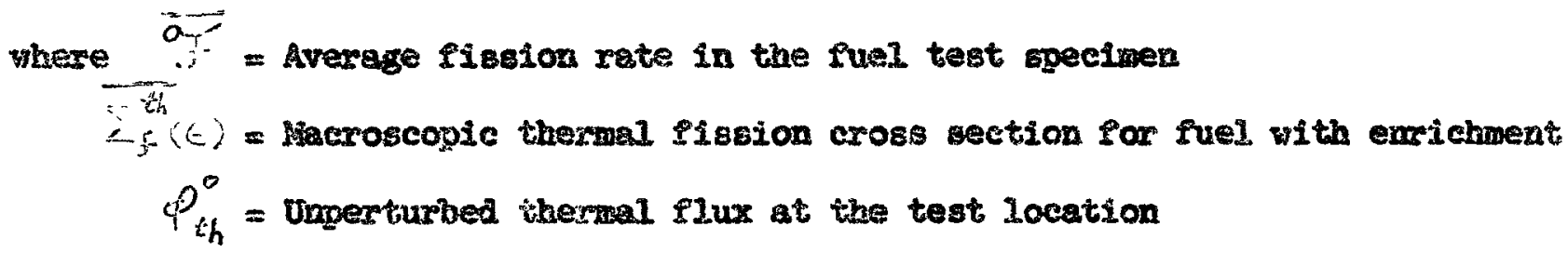

Defined in thie way, it is erident thet the effective self shielding factor inciudes aot only the thernal s?u depression but also the effects of epithermal and last tissions in $v^{235}$ and $v^{238}$. It therefore depends on the local Plux apeetrum as vell as on the aimensions and composition of the fuel cepoule.

In all cases consideret in this sivdy the ungerturbed thermel flux 18 derined as the Plux in the teat hols when Pinled with water stace this is the flux genorally reported by the test resctor operators and is theresore the initial date on which the design of an inpile test is based.

A description of the MIR, SIR and GEIR teat facilities is given in ReP. 1 through \%。 In representing these test sacilivies in an idealized one dimensional cylindricel monkup, the axis of the cylinder in telren as colneident with the axis of the test hole. An attempt is then mede to represent the local regien of the test by a series of radial zones beginning at the ceatier of the hole and continuing out into the resctor core. A zexo gradient boudary condition is then applied the outer boundary. For core test $300 a$ tions this procedure can be carried out vithout much ambigaity. For replector test locations horever the cylindrically aymetric geconetry does not resembie the actual gecnetry very well. For this latter case, the thicknass or seflector material between the core and the test locetion was chosen to give approximstely the correct spectrum at the test location. It is asaured that if the spsetruw is correctly represented, the self shielding factars will also be correct. Tre validity of the calculated apectrum was checked by comparison vith measured cadminun ratios.

The anelytical moekups usec are shom in Figs. 8 through II. For each case a homogeneous DIS calculetion was done using the 16 group cross sections given it IAMS 2543. For hydrogen scattering the linear naisotropic approxination was ubed. The of 38 cepture cross sectioss were corrected for resonanee self ghielding in groups 7 through 12 .

The corrected cross aections as calculated by the GAM II (Ref. II) code are given in Table 3. Since during preliminary calculations very little difference vas observed between 54 and 38 , the study was conducted uBing S4 only. 
As an example of the resulting flux dibtributions, Fig. 12 shows the thermal PIux for a base case i.e. with vater in the test hole and the thermal flux for the same hale not conteining a fuel tost cepsule.

Consiatezt with the derinition of $f_{0}(E)$ (Rq. I) the effective sels ahield factor was obtained frow the calculations as follow:

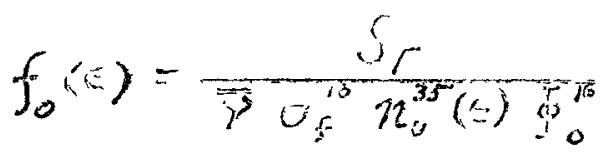

whare $5 \%=$ Total meukros scurce per unit height in the fuel specinen region (frow DIK print out)

$\bar{Y}$ = Average neutrons per Eission in $0^{235}$

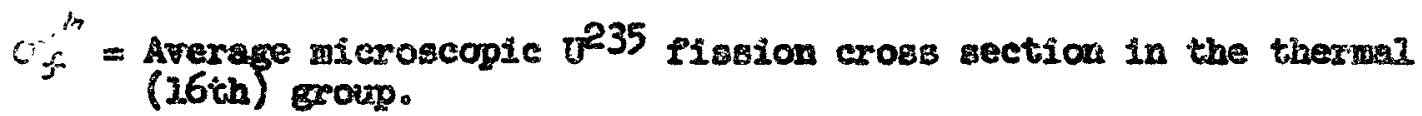

$\eta^{35}(C)=0^{235}$ atomic density in the fuel specimen

$\underline{Q}_{J}^{\prime}=$ Total integratsa thermal (16th gxoup) flur per unit heighis in the centrei region of the leat hole before insertion of the capsule (Erow DTK print out for bage case)

The results of these calculation are given in Teble 1 Lor all cases. Por purposes of exparison the resuits are plotted in Figs. 1 - T.

\section{Comporison of Heasured and Calcuisted Csdinium Ratios}

The calculations yielded approximate $C d$ rat108 Por the BR core, the MTR core and zerlector thich are ahown in Table 2 , aiong with ratios cbtained for severa? locations

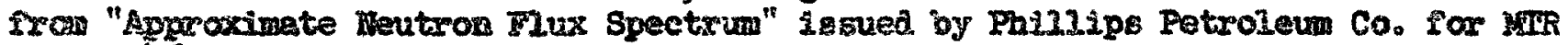
cycle 146 and Cycle 27.

Table 2 shows reasonable agreenent between the values isgued by Fhilips and the celculations except pexhaps in the case of the core filier piece in the wr. Tho difference may be due to the fact thet for the calculations the filler piece is Be three by three inches in cross section with four one-inch holes containiag vater. For the value issued by Phillips the filler piece is grobably aluminum. 


\section{Conclusione}

It is evident in all the figures that a substantial self ahielding effect occurs eveo at, $0.7 \%$ enrichment. This is the slux depression due to 1) displecenent of the water and 2) absorption in the non-fuel reglons of the capsule. As can be seen Irom the Iigures, at low enrichment the self shielding factor is assentialiy independenc of the type of fuel or tuel dianeter. It does however depend on whether the local moderator is water or beryllium (Figa. 3 and 7 ).

As expected the effective self shielding factor decreases monotonically with increesing encichnent. the effect of increasing the fuei dianeter is to reduce the effective self shielding Pactor (Fig. 1). The ols ghielding factor is also zeduced by substituting the more dense Ufi fuel for tC and also by introulucing the tungsten alffusion barrier though in both cases the effect is 3 waII.

In Fig. 3 the results are shown of a calculation in which water was substituted for beryllium in an MTR reflector mockup. This illustrates the fact that for an Laentieal fuel tegt capsule the effective self shielding factor depend on the moderator externai to the capsule. The tendeney towerd larger values of the self shielding factor for a wster moderator versus beryllium moderator is also ceen in F'Ig. 7 aince the GEIR raft Pacility is surrounded by yater.

The exrox to be associated with the preaent results cannot as yet be given since oniy very limited couperisons with experlwent are evajlable. It is planed that, as more impile tests are completed the validity of the calculated results vijl be checked and if recessery zePinements of the analyticel methods will be made.

Of the varicus assuwptions uned in this analysis the following three require Pusther investigation:

1. That exrors are introduced by assuming inilnite cylindrical geonebry?

2. Resonarce self bitelaiag was corrected for in $0^{238}$. Io st wecessary to apply ainilar corrections fon other waterials?

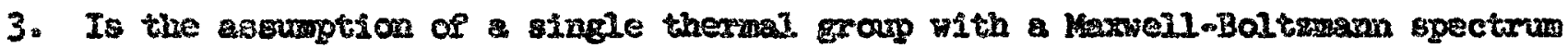
adequate?

WCA/sK: eak
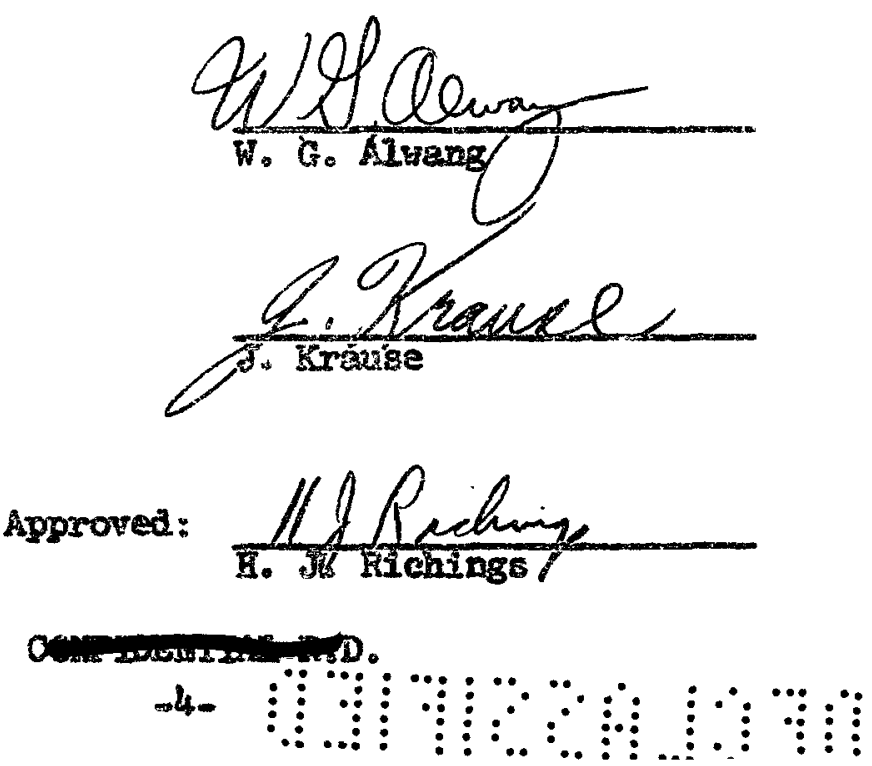
TIM-795, Supp. 2

Aprii 27, 1964

\section{References}

1. ID0-16428, Revision I "In-Tank Irrodiation Facilities In The MIR and EIR".

2. "Cosplete Irradiation Services at Vallecitos" Prom Atomic Pover Equipment Departwent General Electric Co., San Jose, California.

3. AEC.U-3607 (VaI I) "Final Physica Report For The Engineering Test Resctor"。

4. Thacleonics, Var. 15, Bio. 3, March 1957. 
Table I

Tebulation of Calculations

\begin{tabular}{|c|c|c|c|c|c|c|c|c|c|}
\hline \multirow[b]{2}{*}{ Series } & \multirow[b]{2}{*}{$\begin{array}{l}\text { Copsule } \\
\text { Locetion }\end{array}$} & \multirow[b]{2}{*}{ Fuel } & \multirow{2}{*}{$\begin{array}{l}\text { Puel } \\
\text { Diametex } \\
\text { Inches } \\
\end{array}$} & \multirow[b]{2}{*}{$\begin{array}{l}\text { Diffusion } \\
\text { Barrier } \\
\end{array}$} & \multicolumn{3}{|c|}{$\begin{array}{l}\text { Colculated Seif } \\
\text { Shielding Pector }\end{array}$} & \multirow{2}{*}{$\begin{array}{l}\text { Pig } 150 . \\
\text { of } \\
\text { Yocioup } \\
\text { Ueed } \\
\end{array}$} & \multirow{2}{*}{$\begin{array}{l}\text { Fis. Hos. } \\
\text { heere } \\
\text { Series } \\
\text { Resulta } \\
\text { Appeer }\end{array}$} \\
\hline & & & & & $\begin{array}{l}.7 \% \\
\text { Anrich. }\end{array}$ & $\begin{array}{c}10 \% \\
\text { Inxteh. }\end{array}$ & $\begin{array}{c}30 \% \\
\text { Brosech. }\end{array}$ & & \\
\hline 1 & EWR Care & $\mathbb{C}$ & 0.188 & - & .627 & .374 & .202 & 8 & $1,2,4,7$ \\
\hline 2 & EIR Core & $\mathbf{t c}$ & 0.277 & - & .617 & .298 & .145 & $\begin{array}{l}8 \text { vith } \\
\text { fuel dia. } \\
\text { cherge }\end{array}$ & 2 \\
\hline 3 & HER Care & toc & 0.188 & v & .607 & .363 & .196 & $\begin{array}{l}8 \text { with } 6 \\
\text { mil W sur. } \\
\text { fuel }\end{array}$ & 2 \\
\hline is & $\begin{array}{l}\text { MrR Ref1. } \\
\text { (Water) }\end{array}$ & uc & 0.188 & - & .772 & .453 & .236 & 11 & 3 \\
\hline 5 & CWIR RAFT & $\mathbb{O C}$ & 0.188 & - & .727 & .439 & .232 & 10 & 6,7 \\
\hline 6 & HiR RePl. & $\mathrm{tc}$ & 0.188 & - & .622 & .391 & .216 & 9 & 3.5 .7 \\
\hline 7 & BHER Core & OD & 0.288 & - & .615 & .362 & .197 & $\begin{array}{l}8 \text { with } \\
\text { fuel charge }\end{array}$ & 4 \\
\hline 8 & CEIR RAFT & UIT & 0.188 & $m$ & .730 & .424 & .225 & $\begin{array}{l}10 \text { vith } \\
\text { fuel charge }\end{array}$ & 5 \\
\hline 9 & HWR RePl. & ON & 0.188 & - & .609 & .381 & .220 & $\begin{array}{l}9 \text { with fuel } \\
\text { charge }\end{array}$ & 6 \\
\hline
\end{tabular}


Table II

Cadilum Ratios for Cobelt

\begin{tabular}{ll} 
Core \\
\hline Center of Core \\
\hline
\end{tabular}

ETR

$\begin{array}{lcc}\text { Pailips } & 6.9-11.8 & 7.9 \\ \text { Calculsted } & 8.1 & 11.54\end{array}$

nes

$\begin{array}{lc}\text { Paillips } & 7.6 .13 .6 \\ \text { Calculated } & 8.2\end{array}$

Rerlector

$10.3-16.8$

13.8 
TIN-795, Supp.2

\section{Table III}

Won Self Shielded and Self Shielded U-238 Transport Cross Sections

\begin{tabular}{|c|c|c|}
\hline & elf Shielded & Self saielded \\
\hline Groug & $\begin{array}{l}\text { LAMS } \\
25443\end{array}$ & GAM II \\
\hline 7 & 24 & 13.96 \\
\hline 8 & 15 & 14.6 \\
\hline 9 & 22 & 14.44 \\
\hline 10 & 59 & 25.95 \\
\hline II & 65 & 15.72 \\
\hline 12 & 119 & 21.54 \\
\hline
\end{tabular}




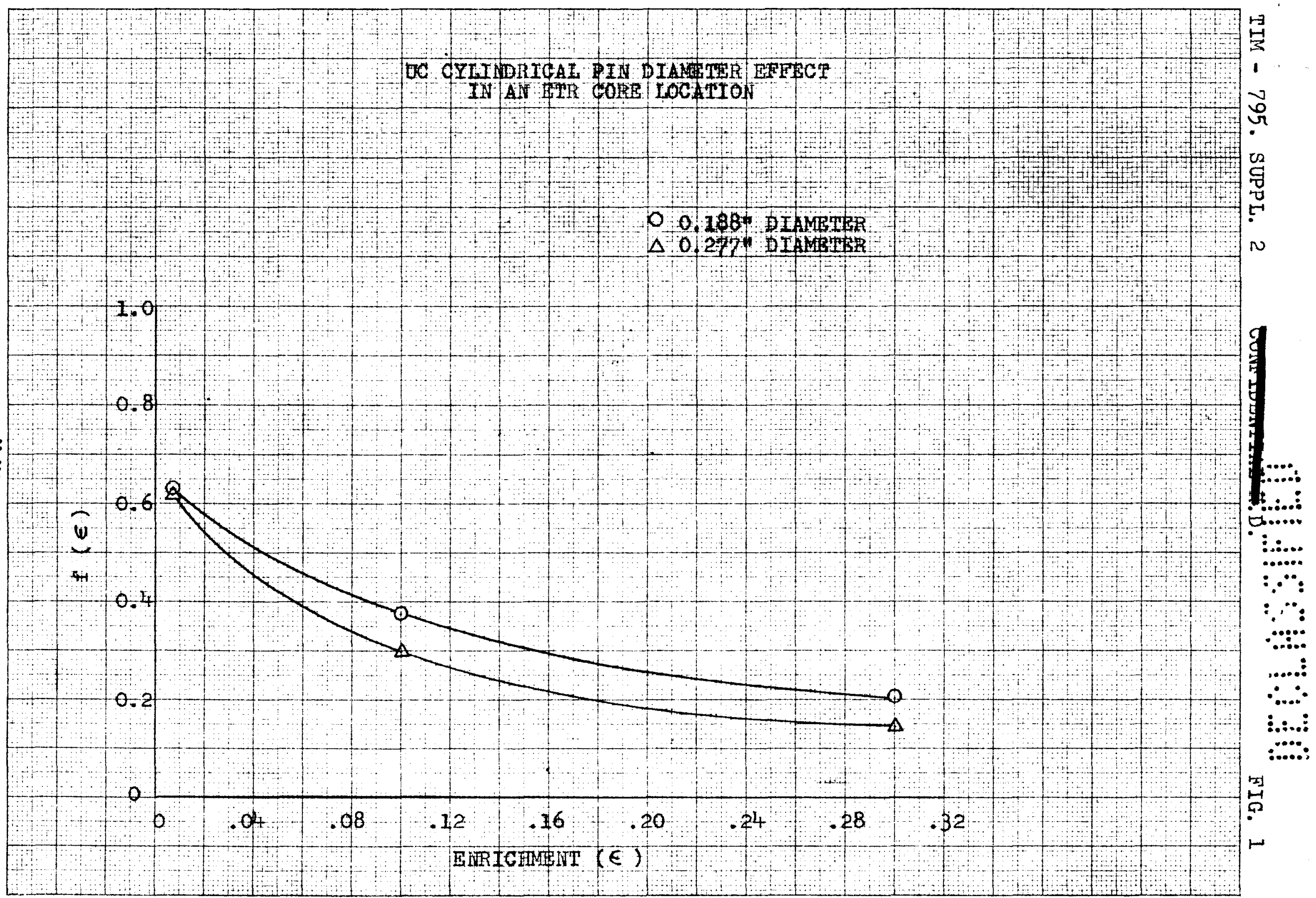


KAE $10 \times 10$ TOTHE CENTIMETET 461513

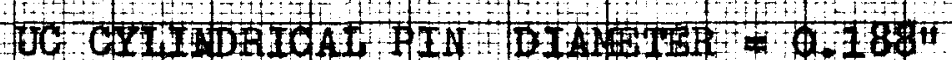

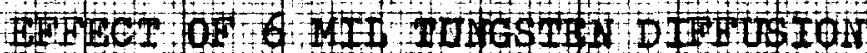

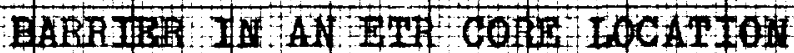

\section{Con}

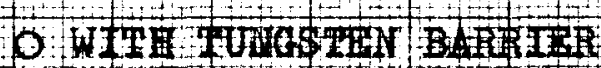

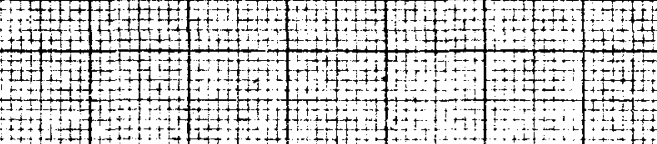

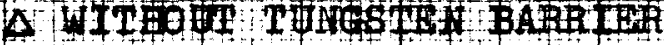
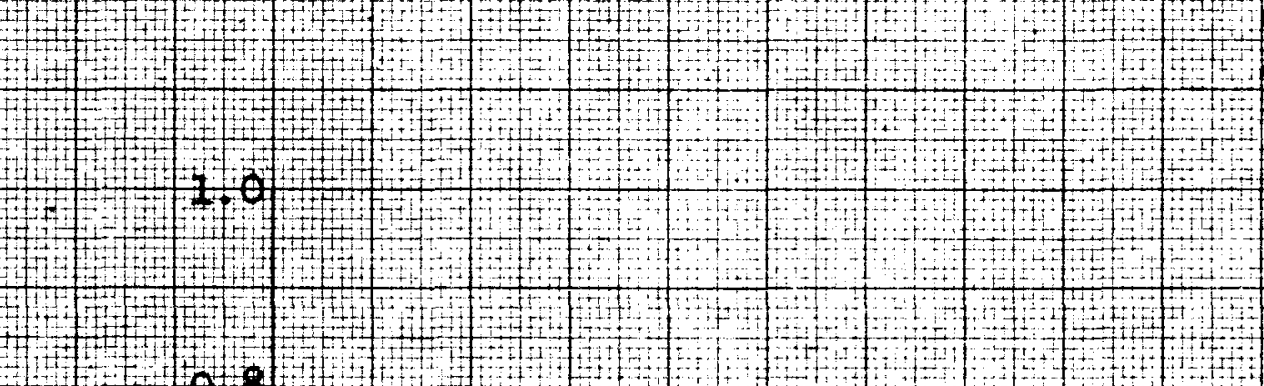

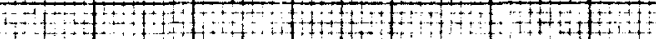

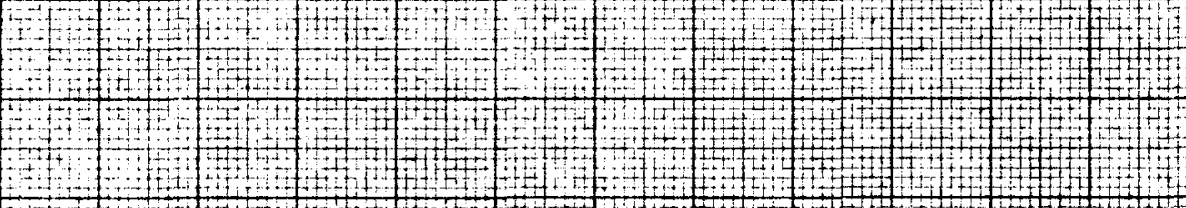

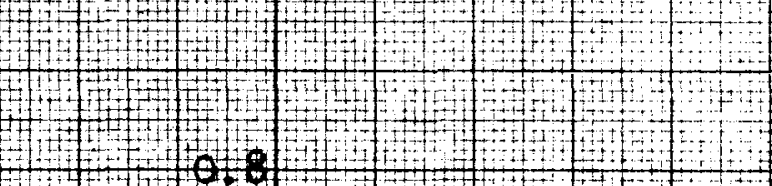

$\cdots$

$(+3+2+4$

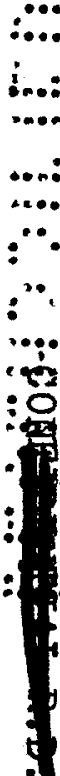
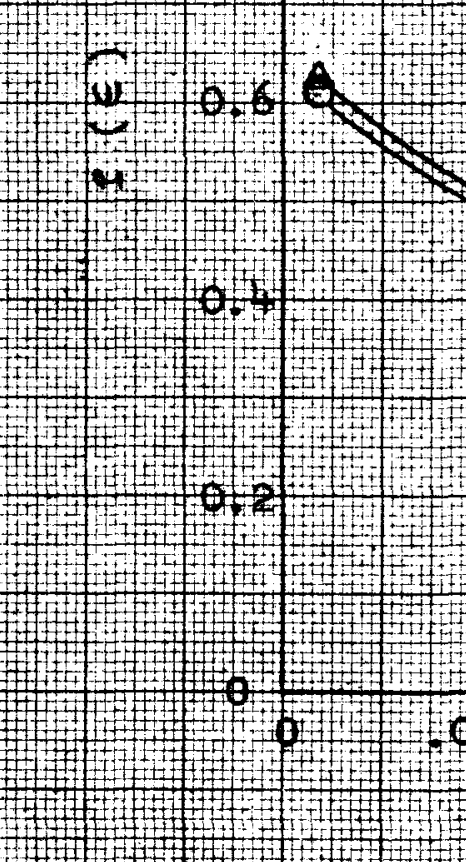

0.4
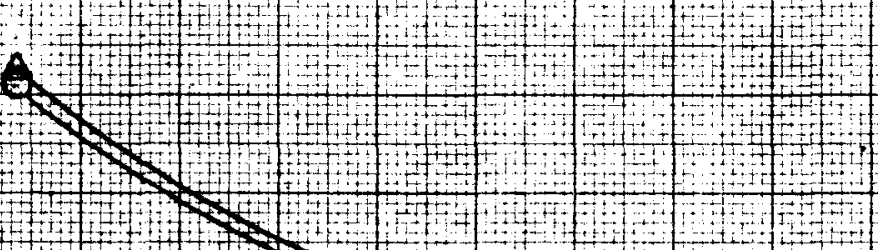

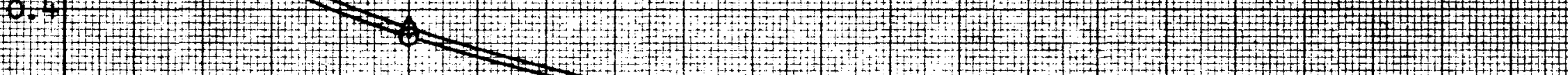

Q+1 +1

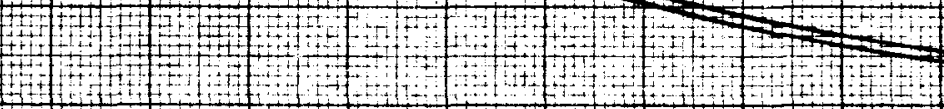

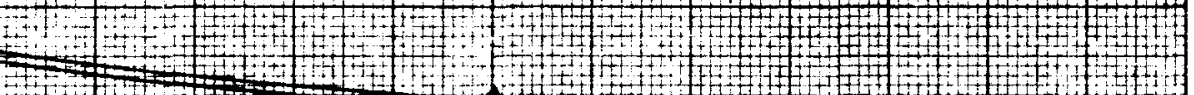

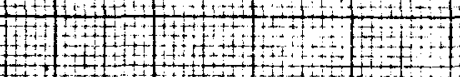

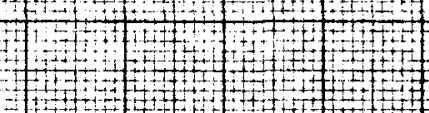

$+1+2$

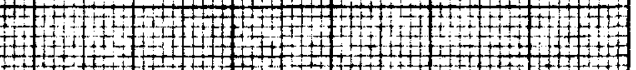

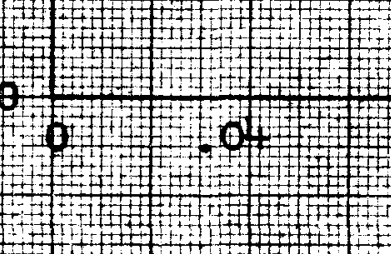

$+$

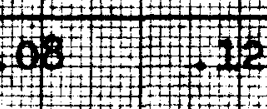




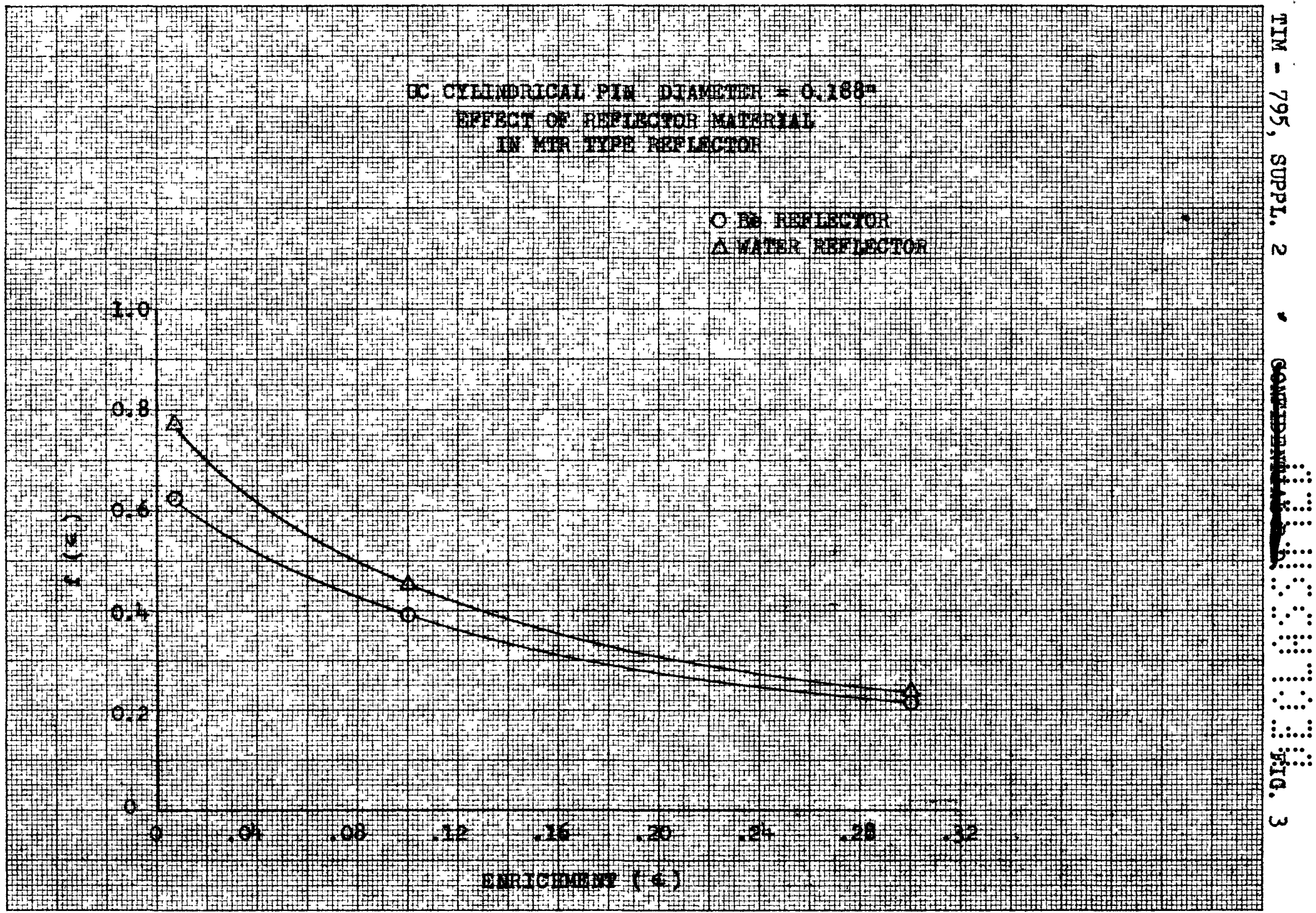




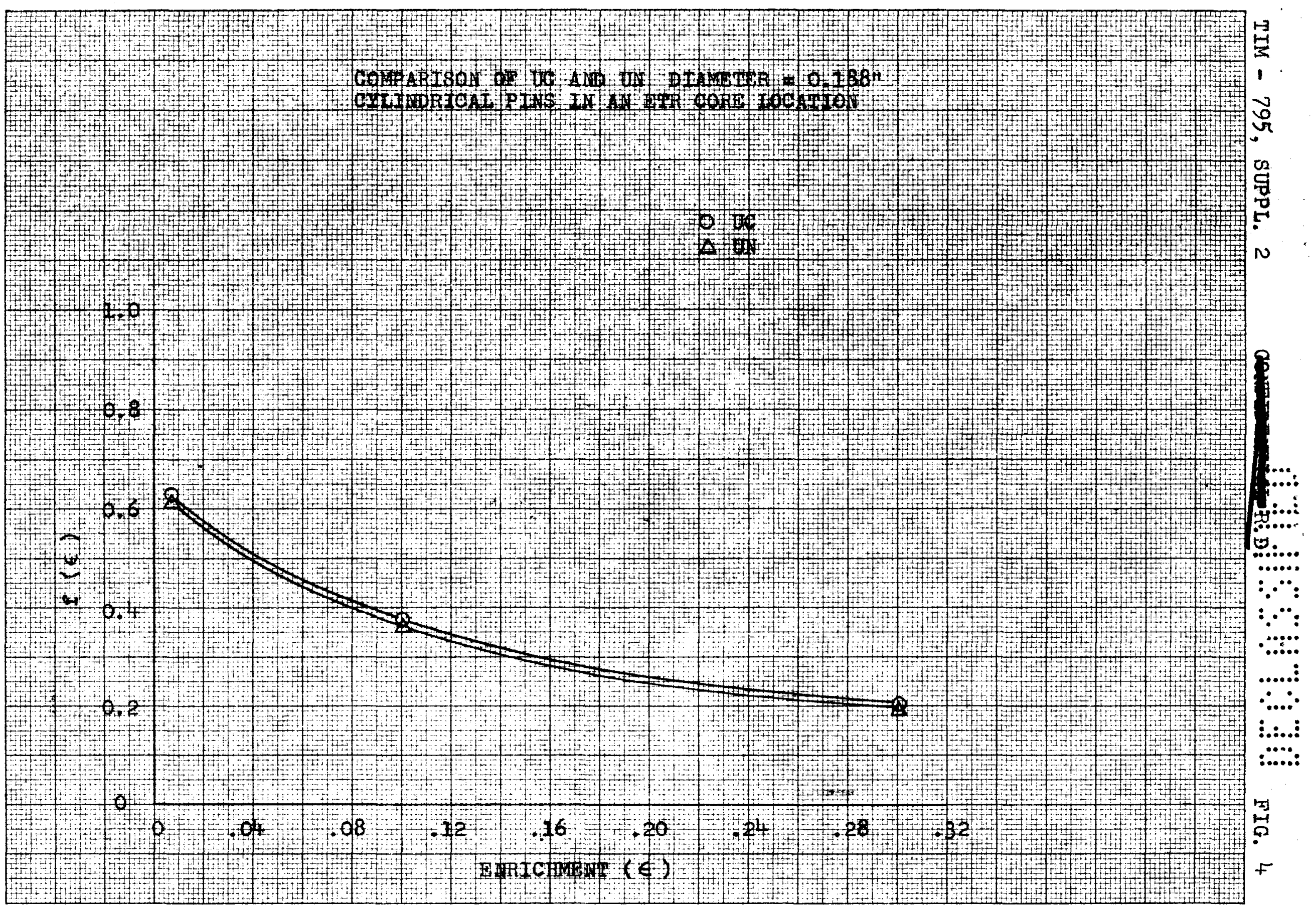









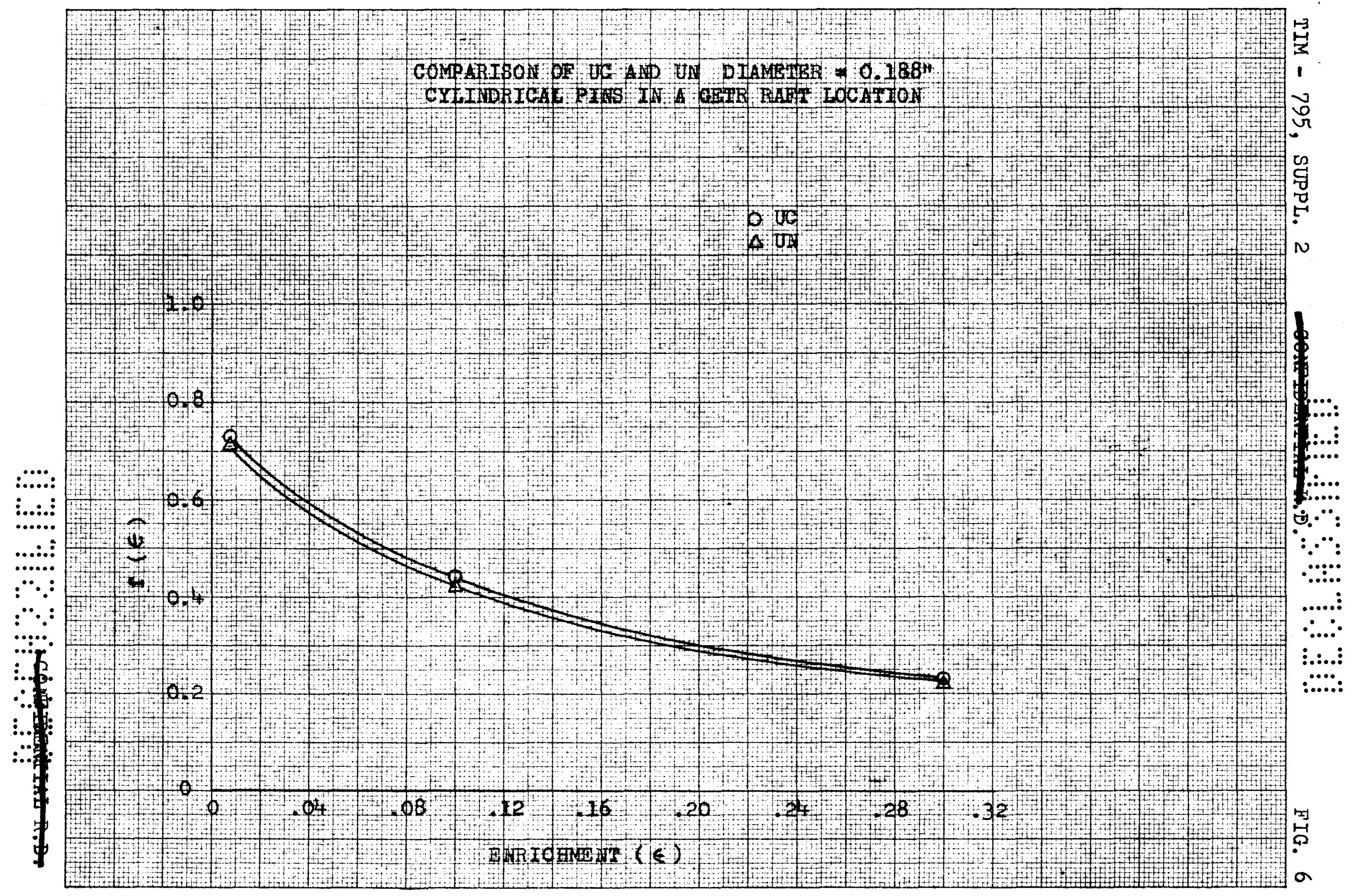


KHE $10 \times 10$ TJTHE CENTIMETER 461513

KEUTFEL \& T.3SER CO






\section{Figure 9}

Cylindrical Wock-Up of $10 \%$ Barlched $0.188^{\prime \prime}$ D1amgter UC Caprule With Atcon Danities (atomo/an $\times 10^{-24}$ ) and Redil in $\mathrm{Cm}$. In MIIR Reflector Location

31.66624

U-235 .00005331, U-238 .000003707, B .00002739

A1 .006127, H .05992, $0 \quad .02996$

15.63624

Be

5.47624

Al .06042

1.66624

更

H .06688, O .03344

1.6383

Al .06042

1.5367

$\begin{array}{ll}\mathrm{H} & .06688 \\ \mathrm{O} & .03344\end{array}$

1.3950

Fe .0611, or .0158, N1 .00988

1.3251

Vold

-

1.2662

Cb $\quad .05332$

Ne $.002841, K \quad .001304$, Fe .006338

Al $.01657,0.02485, C D .01445$

1.1407 .7254

Cb $\quad .05332$

$\begin{array}{ll}\mathrm{II}_{6}^{7} & .03956 \\ \mathrm{If}^{6} & .000003956\end{array}$

.4606

.3175

Cb $\quad .05332$

.254

Void

U-235 .003153, U-238 .02838, c .03153 
Figure 10

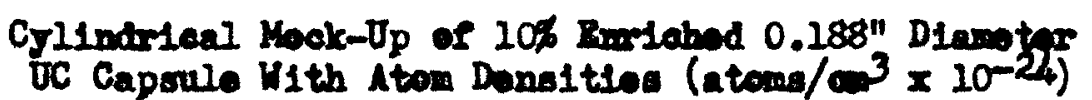
and Radis in $\mathrm{Cm}$. In CISTR RUT Iocation

\begin{tabular}{|c|c|c|c|}
\hline \multirow{5}{*}{ 密 } & $\begin{array}{l}\text { U-235 } .00005331,0-238, .000003707, B \\
\text { Al .006127, } \mathrm{B} .05992,0.02996\end{array}$ & .00002739 & \multirow{4}{*}{$\begin{array}{r}17.4625 \\
9.8425 \\
2.2225\end{array}$} \\
\hline & Al .06042 & & \\
\hline & В $\quad .06688,0 \quad .03344$ & & \\
\hline & Fo .0611, Cr .0158, $\mathbf{~} 1.00988$ & & \\
\hline & H $\quad .06688,0 \quad .03344$ & & \multirow{4}{*}{$\begin{array}{l}1.2750 \\
1.3251 \\
1.2662\end{array}$} \\
\hline \multirow{2}{*}{$\uparrow$} & Bo .0611, Cx .0158, $\mathrm{H1} .00999$ & & \\
\hline & Vold & & \\
\hline \multirow{6}{*}{ 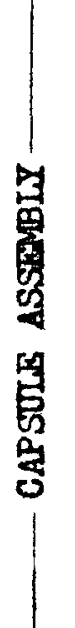 } & $\mathrm{Cb} \quad .05332$ & & \\
\hline & 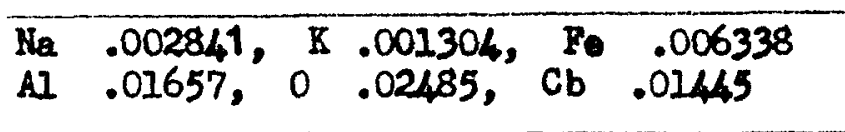 & & 1.2407 \\
\hline & $\mathrm{Cb} \quad .05332$ & & 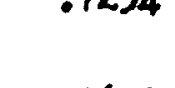 \\
\hline & $\begin{array}{ll}L_{1}{ }^{7} & .03956 \\
L_{1}^{6} & .000003956\end{array}$ & & .4602 \\
\hline & $\mathrm{Cb} \quad .05332$ & & 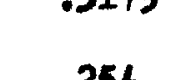 \\
\hline & Vold & & \\
\hline$\downarrow$ & $0-235.003153,0-238.02838, c .3315 \pm$ & & 0 \\
\hline
\end{tabular}


Figure 11

Cylindrical Mock-Up of $10 \%$ Foriched 0.188 " Dimeter UC Capaule With Atomic Dansities (atoras/cm $\times 10^{-24}$ ) and Radil in $\mathrm{cm}$. In Wir with Water Reflector

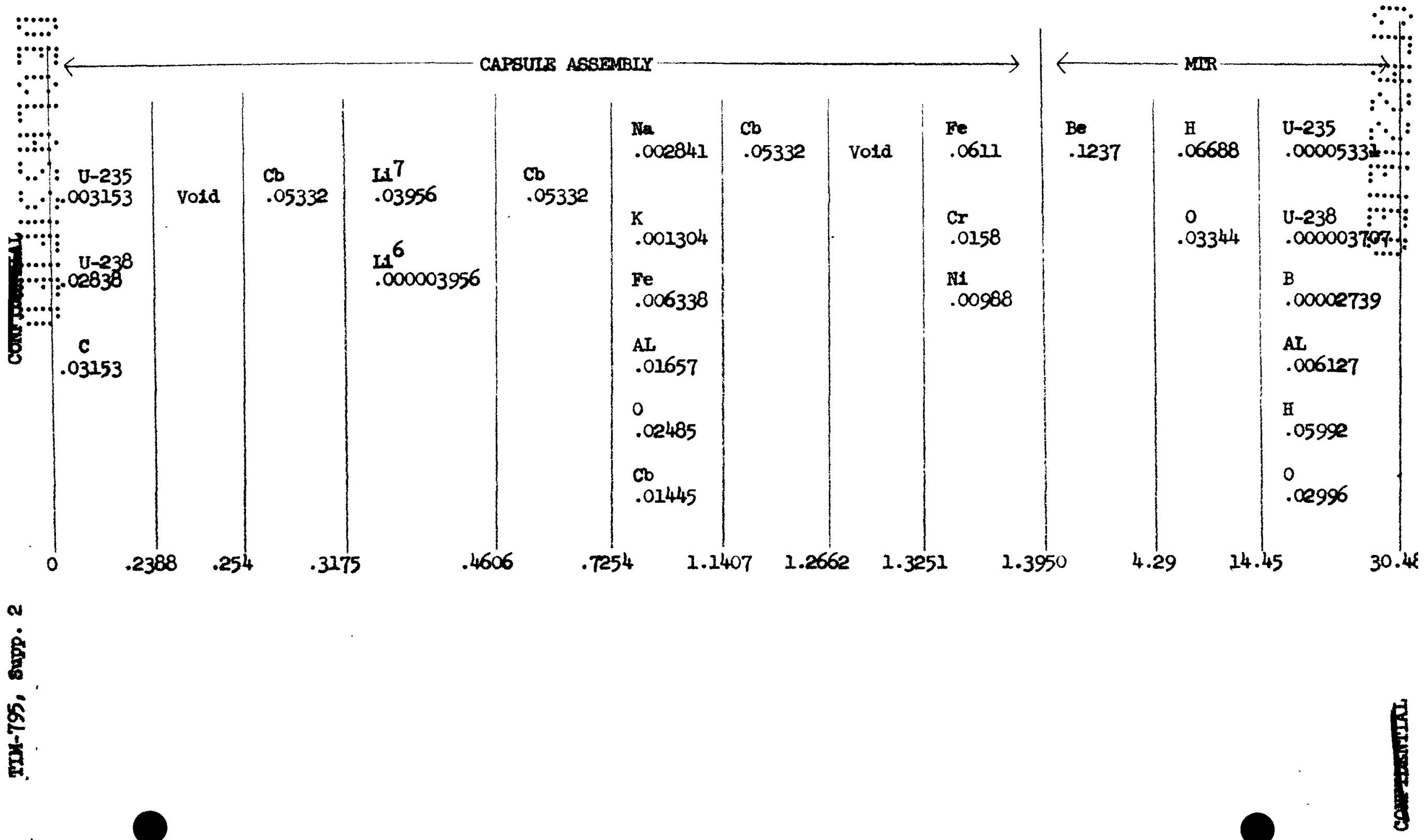




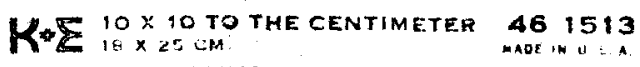

KEUFFEL Q ESSER CO

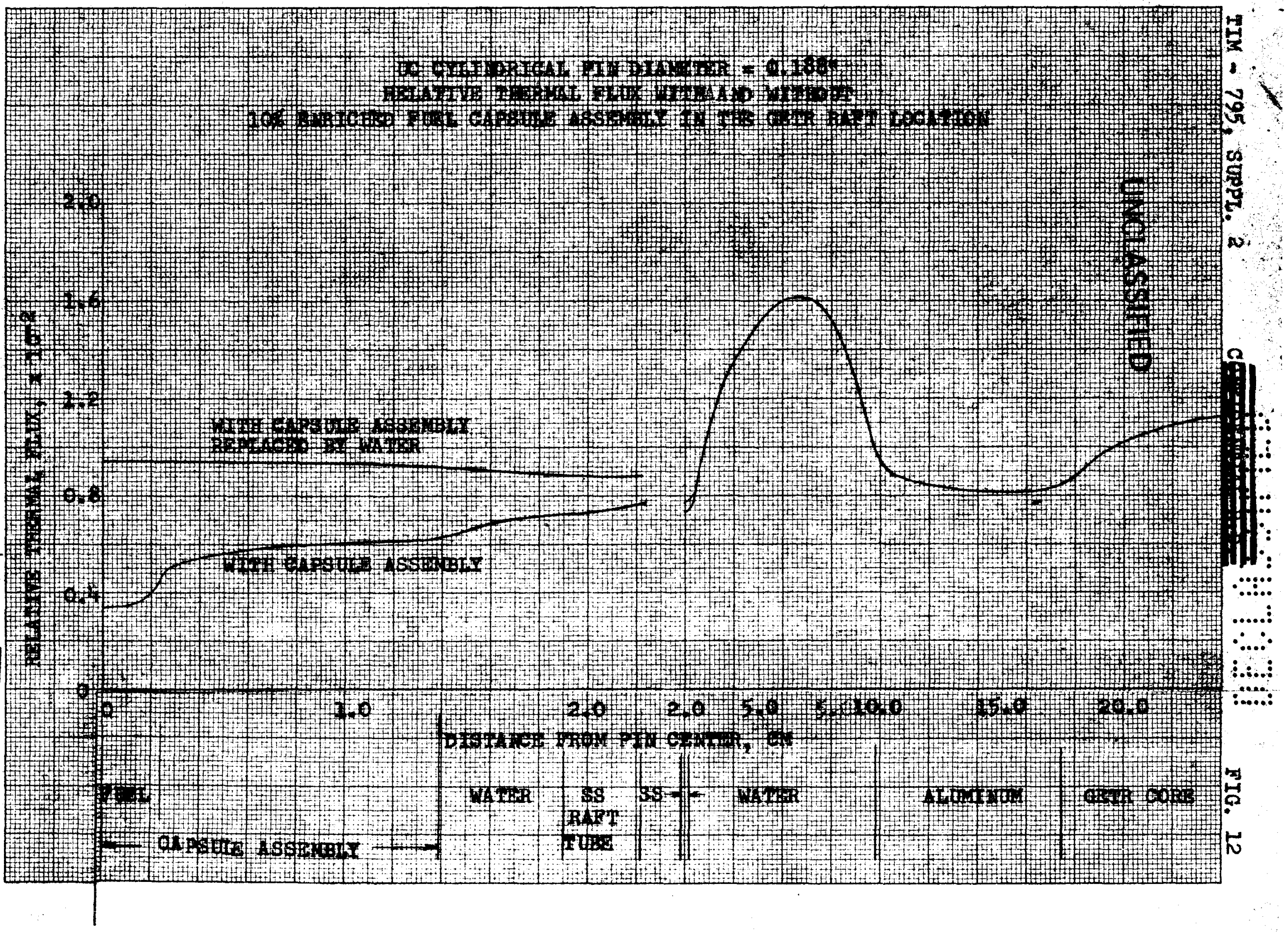

